Les actes de colloques du musée du quai Branly Jacques Chirac

$2 \mid 2009$

Performance, art et anthropologie

\title{
Self Inflicted Wounds: Art, Ritual, Popular Culture
}

Richard Schechner

\section{(2) OpenEdition}

\section{Journals}

Electronic version

URL: http://journals.openedition.org/actesbranly/445

DOI: 10.4000/actesbranly.445

ISSN: 2105-2735

\section{Publisher}

Musée du quai Branly Jacques Chirac

\section{Electronic reference}

Richard Schechner, «Self Inflicted Wounds: Art, Ritual, Popular Culture », Les actes de colloques du musée du quai Branly Jacques Chirac [Online], 2 | 2009, Online since 20 April 2010, connection on 07 September 2020. URL : http://journals.openedition.org/actesbranly/445 ; DOI : https://doi.org/ 10.4000/actesbranly.445

This text was automatically generated on 7 September 2020

(c) Tous droits réservés 


\title{
Self Inflicted Wounds: Art, Ritual, Popular Culture
}

\author{
Richard Schechner
}

1 Why do people wound themselves? Are there advantages in parsing these practices as art history, religion, psycho-pathology, or sociology? But how can we separate art from ritual from pathology from popular culture? Why do not we accept overlapping practices and complex functions? Ought there to be ethical and/or legal limits to selfwounding? What is "self-wounding" anyway? Only wounds caused by the person herself - or would voluntarily sought wounds performed by others such as tattooing, piercing, and cosmetic surgery count? And what constitutes a "wound," tissue damage or subjective experiences and cultural contexts? What about imaginary wounds such as those of Catherine Benincasa, later St. Catherine of Siena, who received the stigmata in 1375 though, the marks remained invisible until after her death? Are the lines sharp or blurry demarking artistic self-inflicted wounds, mental illness, religious rituals, fetishism, and fashion? Don't leave out fashion. It's very important. Are the subincisions of Australian Aboriginals more acceptable than the penis-cutting options offered on BMEzine.com (body modification) or events advertised on torturegarden.com?

2 Has the omnipresence in media and the internet of both real and make-believe violence reduced even the most extreme violence - the 9/11 attack on New York's World Trade Center, torture, the recent Israeli invasion of Gaza, and so many more examples both political and personal - to spectacle? Prior to today's media, violence was commonly represented in the visual arts, theatre, and literature. Is what we see today unmediated or at least less mediated? Doesn't the very process of transmitting events even as they happen and without interpretation or editing transform "real events" into representations? Is the actual physical presence of both enactors and spectators necessary for an event to be "really happening?"

3 If this sounds like an enormous tangle, you are right. I am in the process of wrestling with some mighty problems of non-representational art, art after Duchamp; and with the conflict between free expression and censorship (self and/or collective); and with 
niching - the Balkanization of: artistic conventions and societal rules - that is, the breakdown of the very idea of "one law for all".

4 I will concentrate most of my remarks on the activities of three artists who bleed by cutting, piercing, or sewing themselves. I will try to explain why these practices should be considered in the same conceptual sphere as blood rituals and blood popular culture representations and practices.

5 Blood is the body's most ambiguous liquid. Bleeding can be good or bad; in the post HIV-AIDS world, blood can heal or kill. Blood runs within and under the skin; it nourishes the organs, the brain, even the bones. Usually, people want to keep blood in its place, inside the skin and within the capillaries, veins, and arteries. Blood leaves the body when the skin is cut, ripped, pierced, or battered. If a vein is cut, blood flows softly; but arterial bleeding can be eruptive, draining a person to death after a few minutes. The only natural and regular flow of blood is menstruation. Menstruation affects only females and only for a portion of their lives. In many cultures, menstrual blood is hidden from men. Women take steps to absorb and get rid of the blood. In surgery, blood is sponged away as it appears. But in art, as in ritual, the blood flows visibly, even triumphantly, and is on display.

6 The display of blood is related to public nakedness, both primary (all are born naked) and secondary (some choose to be naked in public). And, although I cannot examine the system here, I believe there is a continuum leading from nakedness as a natural occurrence to genital coverings, face and body painting, hair styling, through to various body modifications brought about by piercings and cuttings, ordinary surgery, and artistic surgical practices such as Orlan's or Stelarc's bionic third hand or robot arm. As Stelarc notes: "It is no longer meaningful to see the body as a site for the psyche or the social, but rather as a structure to be monitored and modified - the body not as a subject but as an object - not an object of desire but as an object for designing", (http://www.stelarc.va.com.au/redesign/redesign.html).

7 Design, fashion, art - trivial from one perspective, but a profound human teleology from another. The endpoint being the remodelling of the human genome.

What is it that Franko B., Ron Athey, and Rocio Boliver do? Franko B. is a heavily tattooed man several of whose performances consisted of his opening a vein in his arm and bleeding on the stage. He has done many such performances. Jennifer Doyle described Franko's 2003 I Miss You at London's Tate Modern, (http://www.frankob.com/text3.htm):

Naked, covered in white body paint, Franko walks down a long canvas aisle. He is lit up on either side from the floor by florescent tubes, and bleeds from calendulas in his arms that hold his veins open as he slowly and ceremoniously walks the length of the canvas towards a bank of photographers at its base. Blood pools at his feet at each end of the "catwalk," where he stands before turning around and beginning his march again. The performance is structured to resemble a fashion show, and the blood splattered canvas Franko leaves in his wake is used to make unwearable, or at least, un-marketable haute-couture, to mummify household objects, and to make pocket-sized souvenir paintings.

9 A ordinary enough response. But then Doyle goes on, in a way very unexpected from a critic:

It seemed to take forever for Franko to complete his walk down the isle, and he repeated this back and forth march several times. As he walked past us, I was unsettled by the intimacy of the piece. Franko seemed honestly vulnerable, noble, 
and, somehow, very lonely. While, to be honest, I felt glamorous for having been invited to attend what was a sold-out marquis event, I also found myself feeling lonely, and helpless. As I watched, I realized that I was worried about Franko. Although always composed, he was, near the end, clearly straining with the effort to keep up his march. But I was also shamefully aware of the inappropriateness of my concern. He certainly knows what he's doing, and it isn't as though I have any claim on him, except as one friend among many.

10 A friend's concern is one reaction. Another comes from Amelia Jones who was a performance theorist:

When I stand, shifting from one foot to the other in the crowd-filled roaring silence of Tate Modern's turbine hall watching Franko B's white body, in I Miss You, traverse an increasingly bloodied catwalk (his feet sticking to the blood after the first traversal, making a strange snapping, sucking sound as he extricates them), I am both definitively separated from his "present" live body (which, after all, is staged like the objectified bodies in a fashion show, their agency evacuated by their production as fetishes "over there," rendering the models "absent" subjects), and absorbed into its inexorable, brute "thereness" (the suck of his feet on the bloodied canvas is my punctum, opening his body to me as receptacle for my desperate projections of my own status as alive). (“Corporeal Malediction": Franko B's Body/ Art and the Trace of Whiteness," http://www.franko-b.com/text5.htm )

11 Franko's website tells us that in 2008 “Franko B has recently decided to discontinue bleeding in performance, and is pursuing other challenging creative strategies, including painting." This was after at least 15 years of blood performing.

Ron Athey's most notorious performance took place in 1994 at the Walker Art Center, Minneapolis. In Four Scenes in a Harsh Life, part of his "torture trilogy" (Martyrs and Saints and Deliverance are the other two) Athey made 2 inch long incisions in the back of his co-performer Divinity Fudge, soaked the blood with paper towels, and then as if hanging out laundry sent the rectangles out over the audience. Spectators knowing that Athey is HIV+ assumed that Fudge was too (he wasn't). A near riot was followed by a scandal. Earlier in Four Scenes, Athey intentionally mimicked St. Anthony by inserting more than a dozen hypodermic needles in his right arm, drawing blood. After removing the needles, two assistants threaded them into Athey's bald skull creating a crown of (not) thorns. As he bled, the assistants carefully mopped Athey's HIV+ skull and forehead. Later in the performance, Athey in a sing-song declamatory style described his evangelical Christian childhood, his forced labor as a preacher-faith-healer. Clearly, Athey is very aware of the religiosity of his performances and the masochistic cathartic power of blood. On his website he writes (using the third person to both tell his story and distance himself from it):

If the inside of your head gets pummelled with enough emotional force trauma to splinter the psyche, you develop ways to punish the body, that fleshy prison which houses pain. [...] The sight of your own blood, brought forth from your own hand, spells an almost immediate relief, a release to the pressure valve. It's a violation that you yourself now control, providing a temporarily [sic] satiation which stifles the nauseating screams and endless insinuations of a world turned inside out. [...] Ron Athey forces the body to transcend its confines. [...] by pushing the boundaries of endurance through artistic expression, he shakes his compassionate epiphany. We all need to break free from the shackles placed upon the individual by society, family, religion, and gender. And possibly through the catharsis of performance, and ritual, we might finally be able to lay to rest the demons who've sent us in search of the respite only a knife or needle could at one time provide. http:// www.ronathey.com/bio.pdf 
So let's compare this to Jane, it's not her real name, a young woman self-cutter, puts the same experience and feeling in simpler terms:

I cut right into the fold of a finger ... It was so sharp and so smooth and so well hidden, and yet there was some sense of empowerment. If somebody else is hurting me or making me bleed, then I take the instrument away and I make me bleed. I say, 'You can't hurt me anymore. I'm in charge of that. (Glucklich 2001: 81)

Ariel Glucklich, in a deep study of self-injury and pain across disciplines and cultures, notes:

The mental life of individuals who injure themselves rarely matches either the traumatic shock that observers attach to injury or the reductive processes of neurological and psychological sciences. If anything, in its complexity and ambiguity, the inner world of self-hurters more closely resembles that of mystics and other technicians of the sacred who acquire, or claim to acquire, "spiritual" power by austerities and discipline. (Glucklich 2001: 81)

Certainly, Glucklich's observation applies not only to Athey, but to Mexican performance artist Rocio Boliver. In 2003 I saw her Cierra las Piernas (Closed Legs) at New York University.

Dressed as a nun, Boliver enters a classroom-cum-theatre where there are about 50 spectators facing a hospital bed. Nearby a movie camera with a capped lens and a TV monitor, not yet turned on. On the bed raised to about a 35 degree angle, Boliver spreads a white sheet. After taking out from plastic bags small boxes and medical supplies which she places on tables to either side of the bed, Boliver lay on the bed and lift her skirt so that everyone gets a clear view of her clean-shaven pudendum. But just in case someone is too far away or has the wrong angel, the cameraperson removes the lens cap and turns on the monitor and a close-up of Boliver's vagina appears on the monitor. Out of a box she takes 5 " long action figure Jesus, with bendable hands and legs, dressed in traditional crucifixion garb of white loincloth and crown of thorns. He is both an infant Jesus and a tiny man, a homunculus. Boliver forms a small bed from cardboard and placed Jesus on it.

17 After setting up a small mirror in front of her so that she can see what's she's doing, she ripped open a package of clinical wipes, spread her legs wide, and applied disinfectant to her pudenda and upper inner thighs as if prepping for surgery. The liquid stains her skin a mustard color. She opens a tube of petroleum jelly and squeezes a dab of it onto a dish. Then she opens a sterile package, and with her right hand takes out a large needle, dips it into the jelly, passes needle-and-thread through a small white cylinder about 3" long. Then, with her left hand she stretches the skin of her right labium and pierces the flesh with the needle. On the monitor a close-up of the piercing appears.

18 Among the spectators are murmurs of what? - shock, sympathy, disgust? - as Boliver's face contorts into a grimace. It takes a big effort to force the needle through her flesh. Boliver draws the white cylinder through the flesh also, opening up a wide hole, like a pierced ear with a large opening. Then she slips the cylinder off and stretches the thick green thread along her hips. She repeats the procedure on her left labium.

19 Next Boliver takes Jesus and wraps him in a red robe. Then she unwraps a condom, slips it over Jesus, his head covered his two feet sticking out. She anoints Him with lots of jelly. His arms extended, the crown of thorns stretching the condom, Boliver slowly and painfully Boliver inserts the Jesus-dildo into her vagina. Blood flows from her vagina. 
As she works inserting the Son of God Boliver, Boliver heaves with heavy "birthing breaths." A painful deflowering. Once Jesus is in as far as she can push Him, Boliver takes the two threads and ties them tightly over Jesus, sewing shut her vagina. This effort gives Boliver a lot of pain.

Then Boliver takes off her nun's habit and shakes her red hair free. Naked, she reaches into a bag for a red bra, stockings, and garter belt. Carefully, so as not to expel Jesus, Boliver puts these on, wearing the bra below and not over her breasts. She has trouble pulling on the stockings because it is painful for her to move her lower body with Jesus inside. But finally she gets the stockings on. Then she reaches fetches a pair of very high-heeled red shoes. Slowly she stands up. The stockings are equipped with a zipper that fastens them to each other. Boliver zips herself up. Ironically, this nun-turnedwhore cannot spread her legs, and locked between them is Jesus. Painfully, she totters to the side of the room. End of performance. A smattering of applause - clapping seems out of place. As does silence. There is no "right" response readily available.

21 I follow Boliver to the dressing room. An assistant removes the green thread and Jesus. Boliver screams and moans, this is truly painful, and out with Jesus comes plenty of blood. Is this the labor of birth, is it part of the performance? Soon Boliver and I are talking. I ask her if she has ever done this before. "No, and I won't do it again." Almost all her performances are one time events. Before Cierra las Piernes she had no body piercings at all. She is very aware of the "nun-whore" conjunction; as well as of the women saint-martyrs of medieval Christianity. But she is also aware of the parody and pop culture, the action figure Jesus, the condom as protection against STDs. And the strong medical overlay, as in many of Franko B's blood performances.

Returning to Stelarc's notion of the body as an object for redesigning, performance artists who bleed: on the lower rungs of this evolutionary ladder. Franko B displays his bleeding self on a mockery of the fashion show runway; but his message, if there is any, is not Stelarc's. Franko, Athey, and Boliver are not modifying their bodies as much as they are performing its irreducible physicality. Ordinarily, what's inside the body issues forth as sweat, spit, tears, vomit, urine, shit, semen, and menstrual blood. Making oneself bleed adds a uniquely personal and cultural possibility to the natural flow of things. It is a way of taking over, of empowerment.

Jane, [an adolescent girl] made a list of reasons for cutting herself in which she included more than thirty items. However, the word that recurred most frequently in that list was power. "I cut right into the fold of a finger ... It was so sharp and so smooth and so well hidden, and yet there was some sense of empowerment. If somebody else is hurting me or making me bleed, then I take the instrument away and I make me bleed. It says, 'You can't hurt me anymore. I'm in charge of that."' (in Glucklich 2001: 81)

Jane is not an artist; her self-wounding operates at a personal private level. Many people of course would say that she is mentally ill. When she takes the knife to herself secretly, is because she wants an audience, she is sending a message. One can variously interpret the bleedings of Franko, Athey, and Boliver - but undeniably they publicly display themselves. Whatever else they are, they are entertainers. They earn their livings by self-wounding.

24 This is not to denigrate the other functions of their performances. Like many artists from the Romantic period forward, the professional bleeders tell their own intimate stories. They frequently invoke and enact a neo-Medieval religious iconography. They play with dying, but in a theatrical way, through allusion more than illusion: to bleed is 
to risk death. There is an erotic at work also, which medical opinion isolates as "masochism," a pathology, but which others see as necessary. As Georges Bataille noted in his l'Erotisme: "If a taboo exists, it is a taboo on some elemental violence. This violence belongs to the flesh" (1986 [1957]: 92-3).

And there is the question of pain. Franko B appears to enjoy what he is doing, while Athey grimaces in pain and Bolivar both grimaces and later cries out as her vagina oozes blood. It was relatively easy to watch Franko, he seemed to take such delight in his performances which he framed as an homage to blood. But it was very difficult to watch Bolivar. Should this matter? Athey appeared to reach a certain calm after the immediate pain of the insertion of the syringes into his scalp passes. Perhaps his natural endorphins took over. Not so with Boliver who suffered with every puncture of the needle and with the insertion and removal of Jesus.

Until the introduction of anaesthesia in the $19^{\text {th }}$ century and a wide range of analgesics in the $20^{\text {th }}$ century, pain was part of daily life. As Glucklich observes:

We have lost our capacity to understand why and how pain would be valuable for mystics, members of religious communities, and perhaps humanity as a whole. The role of pain, before it was displaced, was rich and nuanced, and ultimately situated persons within broader social and religious contexts (201).

Seen in this perspective, these artists are throwbacks, archaic more than avantgarde, recuperating sacrificial violence and sacred terror. In performing their ordeals, they share with audiences something akin to initiation rites, mystical experiences, and sacrifice. Is this kind of art acceptable in "civilized" society? If not, why not? Many perform or wound themselves to show off or because they are sick. But even so, perhaps something more constructive is also operating. Isn't there in the art and in the orgasmic subincisions, bleedings, and piercings of popular culture, a complex mix of pain and pleasure, a Goth-medievalism derived not from a careful study of history, but from fantasy, mass media, comic books, and what's available on the internet?

At the level of performance theory, these acts test the limits of representation. They are non-mimetic. Real blood is really flowing, the performers are not pretending. Of course, even in ordinary theatre something is really happening. The actors are speaking, moving, breathing, etc. But these actions are subsumed into the fictional roles enacted and serve to advance a narrative. For the time of his performance, it is Hamlet not Richard Burton who is speaking - although it is Burton and not Hamlet who accepts the applause after rising from the slaughter that ends the play. In Hamlet no one really dies or is even wounded. But in the kind of blood performances I am discussing, though up to now no one, or very few, have actually died, a Rubicon has been crossed. It is not stage blood that Athey and Franko B shed; those aren't fake labia that Boliver is putting a thick needle through.

Determining what kinds of reality can be staged is an important theoretical question with consequences for more than aesthetics. Up to now, the tendency among performance theorists, me included, has been to expand the purview of: representation - to take literally the notion of "all the world's a stage" and is concomitant "performances in/of everyday life." After Duchamp, anything at all can be art. But blood art and extreme body modification confronts theory with a dilemma. First, there is the matter of taste, of decorum. Are there or ought there to be limits? Up to now, I have found limits politically and aesthetically unacceptable. Anything that people enact and witness voluntarily is acceptable. But I also confess to have doubts. 

outcomes. If reality can be framed as representation, then there are no limits on what can be enacted "as art." Doctrines of free speech will protect all representations. On the other hand, if artists are legally or conventionally prohibited or discouraged from performing these kinds of actions, we give to the "authorities" - legal or critical - the power to set the limits. And here is the dilemma: art and ritual without limits yields some very abhorrent (to me) practices - such as female genital mutilation. If we say, as many do, the determining factor is "free will" and "voluntarism" - if a person wants to sew up her labia, and then let her ... I can accept that, up to a point. The point being deciding when a person actually has the agency she is presumed to have, even the agency she claims she has. But if an artist's claim of having made an independent judgment is to be questioned, who has the wisdom or presumption to decide? Do you by purchasing a ticket or attending a performance endorse the acts performed? Also what about cultures or situations where the basic social unit is not the individual, but kin, the local community, or some other group? I cannot at present work myself out of this dilemma: I am on both sides of the question. communities, two overlapping communities, the meaning of blood changed radically. AIDS was a new disease, incurable, transforming the prime of life into a slow, wasting death. Living with HIV+ blood, as Ron Athey does, or dying of AIDS as many have, was something unexpected at the time. The anger at blood, the fascination with blood, the terror of blood: avoidance and protection were the first response to the disease. But soon artists took notice of the irony. They drew a line from the Christ's all-saving blood to AIDS's killing blood. Drinking the blood of Jesus signified eternal life; receiving the blood of one's lover might mean a long-suffering death.

I began my talk by noting that I was enmeshed in a tangle. It's true - and I have no neat conclusion. In today's highly mediatized world, there is a very strong desire for "the real" (and I, too, wish there were a better word for it). Artists present the real in one way and non-artists enact it in other ways. Cutting and bleeding are ritualized actions, sometimes painful and always evocative. The ritualists seek transformation, the artists seek expression, the teenagers who cut themselves seek empowerment. Or maybe all these groups seek all these things. Franko B, Ron Athey, and Rocio Boliver are three artists among very many who are simultaneously archaic, risky, avant-garde, dramatic, and in their own ways beautiful.

\section{Discussion}

Arnd Schneider: Thank you Richard for this very powerful presentation. In fact, I have some very disturbing questions. Let me ask something very polemically. Do societies who have apparently removed the public quartering and impaling and other things from the public domain need such rituals in the present? Is war performance?

Les actes de colloques du musée du quai Branly Jacques Chirac, 2 | 2009 

words it's a question where voluntarism comes into play. So we can talk about assisted suicide and work down from there, you see. What we normally do is draw conventional lines and make them like natural lines. So, someone is suffering and they say: "turn on this tap" and put me to sleep". Once we say yes to that, and actually I think we should say yes to that, then we can say what about of someone who is mentally suffering, who is in good physical health who says : "give me the pills". In other words, it's hard to draw the line. That line has to be conventional. I am not for any kind of punishment. I am against the death penalty, etc. But in terms of voluntary infliction of pain on oneself or cutting, there are several websites. don't have any choice about whether it's here. The question is how we deal with it and how we respond to it. And that's where truly I have a dilemma: In other words, I do feel there should be conventional limits and I don't feel that those limits can be "enforced" either by critical authorities or legal authorities, because enforcement of limits is also very dangerous. I look at this as a true dilemma, real dilemma: neither choice is acceptable to me. May be someone has a middle way.

As far as war goes: the other paper I gave this week is "Is the attack of the World Trade Center avant-garde art?" In my old age I am tackling some troubling subjects. I hope that I can demonstrate that the attack of the World Trade Center is in line with some of the manifestos of the Futurists, the Dadaists, the Akionists, etc. I want to show that the 9-11 attack was designed as a media event, an attack on people and property, yes, but also an attack on the imagination. I don't want to go in my whole argument here and now, but I think that a lot of what today's terrorist (or jihadist) attacks are, and the response to these attacks that goes under the name of the "War on Terror" are performance events. That these events move in that liminal territory between the actual and the imaginary. The 9/11 attack was an attack a successful attack on the American imagination. We are living through the chain of events now, the world economic crisis, the wars in Iraq and Afghanistan, which is a direct outcome of 9/11. The chain of events goes like this: 9/11 makes inevitable an American military response. But because the US government does not want a repeat of the Vietnam War protests, the American leaders insist that the US can wage a war with a voluntary military force and also that "ordinary citizens" can just go on living life as usual. How that worked itself out is in terms of building up enormous debts both private and governmental. When the debts could not be paid off, the economic system suffered the most severe crisis since the Great Depression of the 1930s. I suppose that Osama Bin Laden, if he is still alive, must be very happy from a strategic point of view. Actually if you go to his website you'll see that in October 2001 he outlined that chain of events.

To get back to your question: I do think that this kind of war, terrorism and the response to terrorism, has become a battle of spectacles. Is this new? I believe that many people in 1815 travelled hillsides near Waterloo to watch the battle that would decide the fate of Napoleon and the future of Europe. War has long been a spectacle: the medieval war, jousts, and so on. Maybe it has only been in the modern period (which is coming to an end, or has already ended) when war was "general" and "total." And even today, by means of media, people watch war as if war was a drama, a spectacle. So the question is not Is war a spectacle?" but "What are the means of producing this spectacle?" In former days, people went out to watch a battle; today the 
battle "comes home" into the living room, on the television set. Even this is not particularly new. In the 1960s-70s, the Vietnam War was called "the living room war." Obviously I would like to see war abolished. But that's not easy. War is a function of power, violence, and greed; and war - if you are not directly in it, but watching it - can also be thrilling and entertaining (whether or not we admit that to ourselves). These are not easy questions for me.

Public: I'll be honest and say that was really hard for me to watch. But I was searching for kind of ways to understand what was going on and it really hit me that you said at the beginning you wanted to ignore psychology. Later on, going and saying - trying to justify this - that's viable for mystics, kind of sacrificial and sacred. So you can justify it that way in order to evoke a sort of bodily transcendence, and using that at the same time as a reason to ignore the mind and the spiritual. You are evoking the mind and the spiritual self to justify this and the same time ignoring the other impacts that this has on the mind and the spiritual self and the other needs of that self. That's an observation may be you can expand upon.

Richard Schechner: I did not use the word "mind", I used the word "psychology" and I should have used the word "psychopathology". I think the mind and the body are a psycho-physical unity. However it is "easier" to work with the body than to work directly with the mind and the spirit. I would say there is a pathological aspect to this kind of self-wounding behaviour. But if we eliminate or discount all those artists who are pathological, we'd have a great emptying of the museums, theatres, and libraries. Some sick people make great art; some healthy people make great art. There's no demonstrable correlation one way or another. And of course I am interested in the "spiritual dimension", but I didn't use the word "spiritual" either. I agree with whoever noted that we don't understand pain anymore; that we live in a pain avoidance world. I am in a dilemma about this. I certainly don't want to return to the epoch of pain, the late medieval period in Europe for example; or the early Renaissance: the hellish imagination of Hieronymous Bosch or the facts of the Inquisition or the torture and persecution of witches, for examples. I absolutely condemn genocide, the Shoah, and other genocides.

But at the same time, I am fascinated by the kind of material I presented today. I intentionally talked about "self-inflicted" wounds, not wounds imposed on people, not torture in the ordinary use of that word. What do I think about sado-masochism as an erotic practice? I do not want to stop people from doing what they want to do as long as they do not harm others, do not victimize others. But I am also aware that this position, if taken without careful examination, is naive. Do people "really know" what they want for themselves? That is why I draw a distinction between teenagers, girls especially, who wound themselves and artist, mature in terms of age at least, who wound themselves. I am trying to work through some very difficult material. As a performance theories, I have to see where the events lead; I have to follow the stream of evidence, as it were. I have to see similarities among the practices of teenagers, ritualists, and artists. To parse out where these practices that seem so similar phenomenologically may be profoundly different in terms of social context or cultural values.

We are all "other" to some other "other". But are we also "other" to ourselves? Can a person be so alienated from herself so that she sees in herself someone who is not herself? Is this the "one who is cut"? And what stance do I as a Western intellectual man take toward Australian First Peoples (aka Aborigines or Indigenous) who cut 
themselves as ritual practice? Is it neo-colonial to intervene? Is it neo-colonial to let the practices be? Where does one draw the line? Do I intervene "softly" by means of joining organizations that, say, oppose female circumcision? Or do I support "strong" intervention by means of law? Or no intervention at all? Can there be analysis and theory without the implication of intervention or the lack of intervention? Are their "universal rights"? Yes, there are enormous cultural differences; and yes also we are all the same species descended from the same supposed "primal couple." Mythology or biological-evolutionary fact? What is the difference between Lucy and Eve? The cultures of the Ndembu, the Aboriginals, and the French may be very different from each other, but the state of mind, the spirit, and the genes of all the peoples within these cultures may be very much the same. So we have to parse out action, mental and psychophysical mental consequences, culture, and ideology. These may contradict each other - within specific cultures as well as among several cultures. Even within a single individual - a person who is at war with herself.

Mette Bovin: This is a question to both Caterina and Richard please. This is about "foam". Richard talked a lot about blood, and the liquid, and all African societies in the old days knew this. There is blood on buildings, blood on: the ground, blood on the ancestors, blood on the initiated during the circumcision. All the "rites de passage" are made with blood, but what about foam, the foam in the mouth? I have studied with Jean Rouch in Niger. Foam is not a constant liquid compared to blood that is always running in our veins. What about the "throating out the mouth"? This is a liquid that comes and goes is it linked with a connection to the deaths? Is it only in trance, and so forth? Because I have seen people falling into trance in Niger who have this, so I want to know more.

Caterina Pasqualino : La salive et tout ça, c'est très important. A Cuba je l'ai montré dans le film. Je crois que ça se voit très bien. La salive qui sort de la bouche renvoie à l'importance de tous ces liquides, c'est sûr. Et tout cela est repris dans la création contemporaine, c'est sûr.

J'ai une question générale concernant la limite de la performance. Une performance, finalement, c'est quelque chose qui dans l'utilisation est faite par les artistes pour aller au-delà des limites. Aller au-delà des limites est un but de la performance. Je voudrais prendre un exemple. C'est celui d'une fille, une performeuse italienne, qui est partie en voyage avec une copine, habillée en robe de mariée, en auto-stop dans les pays arabes. Et elle s'est fait violer.

Richard Schechner: Would the anthropologists here set a limit on rituals? On what is "allowed" and what "forbidden"? And what would the limit be? I assume excision of the clitoris would be over the limit of rituals. Although I am sure that some anthropologists would say: If that's what a particular society wants to do, that's what that society should do. But who is this "society"? The rulers or the girls who are mutilated? We should have a symposium on what are the limits of ritual and performance. History writes its own answer to these things, especially in art - which probably has a wider horizon than even ritual. And yet, paradoxically, art and artists also serve the authorities - at least some of the time. Artists seek patrons, acceptance, and, more recently, buyers. We are now living (in my view) at the end of the Enlightenment, if we have not already gone beyond it. We no longer live in a world governed by reason. And it is axiomatic that at the very paroxysmic end of a historical period extreme things happen. I don't think a hundred years from now we will be doing these kinds of 
performances because we won't be living in this end-of-the-epoch kind of society we are now living in.

A counter argument is that the avant-garde is by definition avant-garde: out in front of and therefore in violation of conventions. But today there is also a traditional avantgarde, an avant-garde that seeks truths in the past or deep within the cultural memories of individuals. Jerzy Grotowski advocated and practiced that kind of avantgarde. So today some of the avant-garde is "avant" and some other part of the avantgarde is "arrière". These blood ritual artists may be part of the arrière-avant-garde.

Public: I have a question about agency. I found this concept very interesting. It's an intrinsic value of secular societies. It's okay to say that people are using their own will in modern western societies. This is sometimes opposed to traditional societies. I would like that you to talk more of this concept of agency.

Richard Schechner: Obviously I personally believe in agency. But I also know that people live in collectives where agency is not so valued. Agency is a function of individualism. If you are not an individual you can't have agency. Maybe your kin group can have agency or your neighbourhood can have agency. But the kind of agency I believe you are referring to needs a "moi" not a "nous". To refer to one of the artists I considered in my presentation, Rocio Boliver. Does she have agency? If you are a certain kind of psychoanalyst you would probably say that she does not. She is acting out certain fetishes, impulses, and obsessions over which she has no strong control. At one level she knows what she is doing and why; and at another level she has no choice in the matter. Why does she display her acts in public? That makes her performance artist. Or does it make her an exhibitionist? Were the women and men who martyred themselves for Christianity saints or exhibitionists - or both? But as I noted before this psychological-medical criterion can be applied to many artists and if you do so you will get negative answers, answers that declare the artists to be "sick." What shall we do? It's a dilemma. Finally, though, I reject the medicalization of art. Or, at least, I say that such "diagnosis theory" is very limiting. If you push me and ask, "Do you want to stop this kind of art or not?" I would reply that there are certain situations where I would intervene. On a case-by-case basis. If a person was in danger of death or serious injury; if a person were very young; if a person were clearly and definitely not in control of her/himself. But, as noted, these are slippery slopes - controlling or limiting artistic expression. The question is difficult with regard to performance, to actual behaviour. It is easy with regard to visual arts or literary arts. No limits on what can be painted or photoshopped or written. But behaviour is something else again.

\section{ABSTRACTS}

People voluntarily and intentionally wound themselves across a wide range of actions from subincision to "delicate self-mutilation" to performance art. Why? Some wounds are required by religion; some are expressions of personal taste and/or popular culture; some are art. Are these conceptual-social domains related to each other? Are they related to surgery? Is self-wounding as 
art a special category? Is there any fundamental theoretical proposition that can encompass all categories of self-wounding?

Les individus qui se blessent intentionnellement le font à travers un large champ d'action qui va de la subincision jusqu'à des formes d'automutilation raffinées, en passant par la performance artistique. Pourquoi ? Certaines blessures sont exigées par la religion, d'autres sont l'expression d'un goût personnel ou d'une culture populaire, d'autres encore sont de l'art. L'auteur aborde ce thème sous différents angles. Ces champs d'expression ont-ils un lien entre eux ? Se rapportentils tous à un acte de chirurgie ? Les automutilations constituent-elles une catégorie spéciale de l'art? Existe-il une proposition théorique pouvant rendre compte de toutes les catégories de l'automutilation?

\section{AUTHOR}

\section{RICHARD SCHECHNER}

Richard Schechner est Professeur de Performance Studies à la Tisch School of the Arts, à la New York University. En mars 2005, a été inauguré le Richard Schechner Center for Performance Studies, au sein du Shanghai Theatre Academy où Schechner est Professeur honoraire. Il est l'éditeur de TDR : The Journal of Performance Studies, et jusqu'a 2009, le Directeur artistique de East Coast Artists. Schechner est l'auteur de nombreux livres parmi lesquels Public Domain, Environmental Theatre, The End of Humanism, Performance Theory, Between Theatre and Anthropology, The Future of Ritual, Performance Studies-An Introduction, and Over, Under, and Around. Ses livres ont été traduits en espagnol, coréen, chinois, japonais, français, polonais, serbo-croate, allemand, italien, hongrois, parsi, et bulgare. En 1967, Schechner a fondé The Performance Group à New York. Avec TPG, Schechner a dirigé entre autres Dionysus in 69, Mother Courage and Her Children, Oedipus, The Tooth of Crime et The Balcony. En tant que Directeur artistique de East Coast Artists, Schechner a mis en scène ses propres versions du Faust, Faust/gastronome, Three Sisters, Hamlet, and YokastaS Redux (co-dirigé avec Saviana Stanescu), et Swimming to Spalding. Il a dirigé The Cherry Orchard avec le Repertory Theatre de la National School of Drama à New Delhi, Ma Rainey's Black Bottom de August Wilson pour le Grahamstown Festival en Afrique du Sud, Tomorrow He'll Be Out of the Mountains de Sun Huizhu au Shanghai 'Peoples' Art Theatre et The Oresteia (dans son adaptation) avec le Contemporary Legend Theatre de Taiwan. En 2007 à Shanghai, il a dirigé Hamlet: That Is the Question - une version expérimentale des pièces de Shakespeare en tournée en Europe en 2009 et en 2010. Schechner a dirigé des workshops sur la performance en Europe, en Asie, en Afrique et en Amérique latine. 